\title{
ONLINE PSYCHODRAMA AND ACTION METHODS: THEORIES AND PRACTICES
}

\author{
Maria da Penha Nery ${ }^{1, *}$ [C]
}

\begin{abstract}
This article is a study of psychotherapy and sociotherapy practices developed in virtual environments during the Covid-19 pandemic. Online action methods were applied, among them: psychodramas, sociodramas, spontaneous theaters and dramatic games. As an objective, we sought to understand the specifics of these methods. Methodologically, analyzes of the information and of the socodynamics of these encounters were conducted, where we confirm or refute hypotheses related to the therapeutic specificities and effects of online practices. From the analysis some phenomena were found, which were defined theoretically and practically, such as hyper-supplementary reality, interconnecting scenes, virtual tele, virtual therapeutic bond, condensed corporality, speech-action, dynamic sociocultural matrix, and virtual psychodramatic role.
\end{abstract}

KEYWORDS: Online psychotherapy; Online psychodrama; Virtual environment; Action methods; Pandemic.

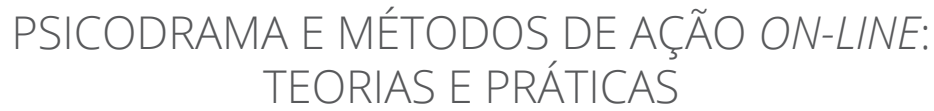

\section{RESUMO}

Trata-se de um estudo de práticas psicoterápicas e socioterápicas desenvolvidas em ambiente virtual, no período de pandemia da Covid-19. Foram realizados métodos de ação on-line, dentre eles: psicodramas, sociodramas, teatros espontâneos e jogos dramáticos. Como objetivo, buscou-se compreender as especificidades desses métodos. Metodologicamente, foram realizadas análises da informação e da sociodinâmica desses encontros, por meio das quais confirmamos ou refutamos hipóteses relativas às especificidades e aos efeitos terapêuticos do atendimento on-line. A partir das análises, foram encontrados alguns fenômenos, definidos teórica e praticamente, dentre eles: realidade hipersuplementar, entrecruzamento de cenas, tele virtual, vínculo terapêutico virtual, corporalidade condensada, fala-ação, matriz sociocultural dinâmica e papel psicodramático-virtual.

PALAVRAS CHAVES: Psicoterapia on-line; Psicodrama on-line; Ambiente virtual; Métodos de ação; Pandemia.

\section{PSICODRAMA Y MÉTODOS DE ACCIÓN ONLINE: TEORÍAS Y PRÁCTICAS}

\section{RESUMEN}

Se trata de un estudio de prácticas de psicoterapia y de socioterapia desarrolladas en ambiente virtual, en el período de pandemia del Covid-19. Se utilizaron métodos de acción online, entre ellos: psicodramas, sociodramas, teatros espontáneos y juegos dramáticos. Como objetivo, buscamos comprender los detalles de estos métodos. Metodológicamente, se realizaron análisis de la información y de la socodinámica de estos encuentros, donde confirmamos o refutamos hipótesis relacionadas con las especificidades y efectos terapéuticos de la atención online. A partir de los análisis se encontraron algunos fenómenos, los cuales fueron definidos teórica y prácticamente, entre ellos: realidad hipersuplementaria, interconexión de escenas, tele virtual, vínculo terapéutico virtual, corporalidad condensada, habla-acción, matriz sociocultural dinámica, rol psicodramático-virtual.

PALABRAS-CLAVE: Psicoterapia online; Psicodrama online; Ambiente virtual; Métodos de acción; Pandemia.

\footnotetext{
1.Associação Brasiliense de Psicodrama - Brasília (DF), Brazil.

*Correspondence author: mpnery@gmail.com

Section editor: Amanda Castro

Received: 23 Nov 2020 | Accepted: 29 Mar 2021
} 


\section{INTRODUCTION... WHAT A MOMENT IN OUR LIVES!}

Since March 2020, the pandemic of the disease caused by the coronavirus, called SARS-CoV-2 (Covid-19), has produced personal and collective suffering. One of the struggles of this pandemic was social isolation. Since then, healthcare professionals have sedimented online medicine (telemedicine, telehealth) and telepsychology. Technology and virtuality brought challenges to everyone who works with physical, mental and collective health (American Psychological Association, 2013; Conselho Federal de Psicologia, 2018).

Regarding online psychotherapy, for example, studies show that the success of this practice depends on understanding the new perspectives and current challenges (Ulkovski et al.,2017). Other studies claim no difference in therapeutic results between face-to-face and online care (Pieta \& Gomes, 2014; Thompson, 2016). Moreover, Novotney (2017), in turn, reflects on the ethical issues of these treatments.

Fleury (2020) presents us with research on online psychotherapy and the work of psychodramatists, concluding that Moreno (1993) is being updated in his ideals regarding the use of communication media. In this sense, Imholz (2008) makes an excellent discussion of the application of online psychodrama with the use of role-playing and dramatic games. Recently, in Brazil, the book Psicodrama Virtual (Echenique, 2021) was released, in which professionals in the field report their reflections and experiences during the pandemic period in search of the spontaneity-creativity path in digital service.

Here is the new, the surprise of this quarantine period for us socionomists (or psychodramatists): the effective use of therapeutic methods of online action. These methods, including psychodrama, sociodrama, spontaneous theater and dramatic games, have the primacy of encounter, here-now and spontaneity-creativity.

Throughout the year, we participate in several therapeutic meetings, and we carry out some of them using online action methods. In this article, we will present a study on these meetings, in which we observed some phenomena and defined them in theoretical and practical terms, among them: hypersupplementary reality, the intersection of scenes, virtual tele, virtual therapeutic bond, condensed corporality, speech-action, sociocultural matrix dynamics and psychodramatic-virtual role. We do not intend to exhaust the reflection but contribute to the joint creation of knowledge with professionals in the field.

\section{THE IMPACT OF VIRTUALITY ON THE HERE-NOW OF SOCIATRY}

Working with the virtual environment requires us to rethink the realities in which we live. Moreno (1993) distinguishes four realities in our lives: the social reality, the sociometric matrix, the external society and the supplementary reality. Furthermore, at that moment, online sociatrics, which occur in the virtual environment, on internet platforms, make us reflect on the reality that occurs in the dramatic context of this practice.

The sociometric matrix concerns invisible sociometric structures related to affective interactions, such as the social atom and psychosocial networks. Objective formal or informal groupings make up the external society, which contains interpolations of resistance to needs, expectations and desires. Social reality is the dynamic synthesis of the sociometric matrix and the external society (Moreno, 1946/1984). Social reality is the combination of what is visible with the dynamics and pattern of co-unconscious exchanges and what is invisible in human relationships.

In the sociatric session, we experience these realities crossed by the social, group and dramatic contexts. In the social context, we play social roles, which are the sociocultural units of conduct; in the group context, we experience, with the members of the group, the continence of the sociatric process; finally, in the dramatic context, we give life and action to the imaginary, and therein comes the supplementary reality. For Moreno (1946/1984), the supplementary reality is a new, extended and multi-dimensional experience of social reality. The action techniques used in the supplementary reality make the contents of the sociometric matrix more visible and those of the social reality more co-conscious. During the session, the director coordinates the meeting, following the phenomena and contents of the group. The auxiliary ego gives emotional support and is ready to exercise the characters of the protagonists. Both promote continence to the affections and concerns of the participants of the event. 
When carried out in the virtual context, the methods of online action can bring the specificity that the supplementary reality experienced in the dramatic context expands since the dimension of the imaginary is combined with the dimension of virtuality. The paradox of the online physical presence of the participants (or who were remotely present), which is not the presence in the same physical environment, will demand the exploration of the imaginary together with the dramatic experience in the virtual field for co-creation. For this union, we proposed the term "hypersupplementary reality".

Based on the realities defined by Moreno and the attendance in virtual environments, we try to verify the following hypotheses concerning psychotherapeutic and sociatric practices online: 1) Psychodrama and other methods of online action maximize the supplementary reality in the dramatic context, making it a hypersupplementary reality; 2) The minimal body expressions and the resources of the virtual platform contribute to the development of the sociatric session; 3) The bonds in the virtual environment suffer the same interference from chaotic elements of the coinconscious that occur in social reality. However, the technology demands greater availability of the auxiliary ego or auxiliary ego function of the director to maintain the warm-up, differentiation and sharing of the scenes that intertwine.

\section{RESEARCH METHOD}

Psychodrama action research is based on the epistemology of intersubjectivity, the moment and the relational phenomenon (Brito, 2006; Nery et al., 2006). In this study, we seek to understand the therapeutic relationship in a virtual environment based on the following questions: how do therapeutic methods of online action take place and produce effects on their clients? What are the specifics of online action methods? We removed from these questions the hypotheses previously mentioned.

The methods of action belong to socionomy, the science of relations and groups, created by Moreno (1993). Socionomy is subdivided into three areas: sociometry, the study of group configurations based mainly on affective choices and socio-cultural identifications; sociodynamics, the study of the dynamics and patterns of relationships and groups, by unveiling coinconscious contents; and sociatry, a set of therapeutic methods of action, which works on the sufferings of individuals and groups and seeks to develop spontaneity-creativity. Some methods are: psychodrama works the protagonist, a participant who represents the group in their sufferings and issues; sociodrama works with society and group themes; spontaneous theater promotes creativity through the spontaneous performance of participants in characters in the scenes; and the dramatic games give the opportunity, through mainly playful tasks, for the participants to get to know each other and work on their themes.

We did a systematic analysis of the online sociatric meetings we participated in or held throughout the year 2020, reviewing recordings, making records, and theoretical processing right after each meeting. We had the support of González-Rey (1999/2002) and Nery's (2012) information analysis. For these analyzes, we observed mainly the following elements: the scenes of the therapeutic relationship and the clientele (patients and groups), characters, interactions, body-built images, dialogues and speeches. Through these elements, indicators (examples or signs of the phenomenon) emerged, combined by similarities or appearing isolated. This process brings us the zones of meaning, reflections obtained according to a set of indicators of the phenomenon (GonzalezRey, 2002). They help us to check hypotheses, review concepts and develop some for understanding online therapeutic practice.

It is, therefore, an extensive study, with examples of different practices, and not intensive, which would be to deepen a case with its examples. Our object of study was online practices throughout 2020, and the focus was on online technical management. Epistemologically, we follow Moreno (1993), with action research, and Gonzalez-Rey (2002), who states that the researcher, throughout the research, develops theories and reviews his hypotheses while systematically analyzes (and interacts with) his study object.

Next, we will present the four meaning zones found.

\section{THERAPEUTIC BOND AND VIRTUAL TELE}

Psychotherapy or online sociatry introduces us to the virtual here-now in its complexity. In his first online session, a patient told me: "I am here, and so are you, even though we are not." We live an existential paradox of presence-non-presence, like a real-fanciful-imaginary dream that happens in the images on the screen. 
The virtual therapeutic bond is what we establish with our patients and clientele in online sociopsychodramas. It is configured within the virtual environment, maintaining the basic assumptions of the helping relationship with ethics and trust.

The creation of the virtual therapeutic bond does not have a physical presence, but it has a direct and intermediated relationship through the electronic device screen. The canvas becomes a means that can facilitate the continence of affections in the social network. A patient said: "our psychotherapy, even though it is online, now in the pandemic, is being one of the best times for me. It is a relieffor my loneliness and depression. I can meet with you, even here?".

As we warm-up to the virtual therapeutic bond, sociometry deepens: we move, get up, approach the screen and use the resources of online platforms to get to know each other, choose ourselves, reject each other, meet and confront each other. At the beginning of an online course on psychodramatic psychotherapy, I was told: "I am glad you asked us to chat privately with each other. I really wanted to talk to some people I saw on the screen, I wanted to meet or talk to others again".

Sociometry finds space in the image, in the imagination, to amplify the tele phenomenon. Tele is the exchange of subjective contents that release spontaneity-creativity, promoting collective creation. In the virtual environment, the virtual tele occurs, that is, the intersubjective exchange of affections and the choices that promote co-creation.

A patient says to me: "When we play the characters or work with the symbols, I can see myself, here on the screen of my cell phone, and redo what makes it difficult. Everything is less distressing". She tells us about the differentiation between us, about her internal characters that suffocate her and mix with her self. The action techniques used online help her develop the virtual tele, which unlocks her spontaneity-creativity.

In this pandemic period, through technology, our social roles as a psychotherapist, therapist, patient or group member undergo a ritual of relearning performance, expression and help.

\section{PSYCHODRAMATIC-VIRTUAL ROLES AND HYPERSUPLEMENTARY REALITY}

The imaginary experience brings us images, symbols and ideas about what is considered to be reality. Imagination is the motto of action methods. Through these methods, we "dream" in the "as if" space, or in the dramatic context, we live fantasies, desires and recreate scenes from life.

The constant tension between the real and the unreal is in the gap between fantasy and reality by Moreno (1946/1984). This tension arises from incompleteness, imperfection, the tragic, uncertainty and insecurity. Imagination and fantasy can breathe us, to a greater or lesser degree, in relation to emptiness and existential lack. For the author, a reality that articulates with unreality allows the actor to assume the creator's place and experience freedom concerning his nature and develop spontaneity-creativity.

Also, for Bachelard (1994), imagination is the dynamic function par excellence of the human psyche. It is the capacity of man that makes him human. Daydreams make us lucid dreamers who reflect and imagine. In everyday life, synthetic moments arise, in which there is awareness of dreaming and in which we are, at the same time, clear and dreamy spirits. If the function of the real dominates us, we are oppressed and do not create. According to the philosopher, the function of the creative imagination is the basis of creation.

In turn, Naffah (1997) brings us the concept of imaginary roles, which are in the imaginary field. They arise from feelings and desires that may or may not be repressed. In the dramatic context, these roles are played by psychodramatic roles. Psychodramatic roles are specific to the supplementary reality of psychodrama. The protagonist, therefore, acts in his imaginary roles or relives the scenes of his social reality through psychodramatic roles.

These Naffah definitions of psychodramatic and imaginary roles have helped us to see that online sociatry brings out what can be termed a virtual psychodramatic role. In online dramatization, this role is experienced simultaneously in the virtual environment (internet platform) and in the dramatic context, in which the "as if" of the methods of action occurs. The psychodramatic-virtual role results from the enhancement of imaginary capacity when the warm-up for action in the dramatic context also occurs in a virtual environment. The dramatic context produces the supplementary reality. When we live the psychodramatic-virtual roles, the junction of this context with the virtual environment takes us to a new reality, 
the hypersupplementary. This reality integrates the imaginary, the social reality and the therapeutic bond in the virtual environment. The performance in "as if" and on the online platform combines virtuality and imagination.

Therefore, in online therapeutic works, the lack of delimitation of the scenic space demands that we make it explicit. It is important to make clear, verbally, the stage of the dramatization, the entry and exit of the characters, so that the supplementary reality is evident within the virtual reality. At the time of online dramatization, the hypersupplementary reality will emerge from the combination of interconnected realities in the virtual environment: the social, the imaginary, and the supplementary.

Let us bring an example of a hypersupplementary reality in the experience of Sociodrama: Diversity Forum, held at the first Brazilian Congress of Psychodrama online in October 2020. In this sociodrama, we warmed up the group to live a "social forum of diversity". We asked the participants to imagine themselves in social minorities chosen by the group, who were Indians, gays, disabled people and black people. At each moment, we said that we would all go to the "room of a minority", and in it, we would live a character of that minority (who could be the person himself or someone known). We demarcated the dramatic context with the scripts for the characters and their bodily expressions. For example, at the time of the experience in the LGBTQIA + room, gay characters expressed their pain in scenes of prejudice. Some participants offered to play prejudiced characters. The scene intensified through chat, emoticons, visual effects provided by the platform, sounds from internet videos, or participants moving away and approaching the camera. Other characters appear to give support or to help to elaborate the claim documents for the society and the authorities. These claims would be taken to everyone in the end.

We observed that virtuality brings us the paradox of presence/non-presence: we are present through digital means. In the virtual environment, we can, for example, use various technological resources of the platform or the internet. The specificities of this environment can contribute to the broadening of the imagination in the dramatic context, bringing us the hypersupplementary reality.

This sociodrama can be seen as a microcosm of society and the Congress itself. The dynamic socio-cultural matrix revealed macrosocial aspects in the microsocial, and vice versa, and demonstrated how cultural conserves are in our bodies, conduct, speech and relationships.

The crossings between the social, group and virtual contexts occurred during the online congress. We observed that virtual sociometry continued to develop, that is, people identified themselves, attracted, moved away, formed subgroups continuously. Some minorities, LGBTQIA +, disabled people, blacks and women, reported the prejudices experienced at the event. Some people acted as if they were social actors, representatives or spokespersons for these minorities. On the virtual platform, the new generations interconnected intensely through the corridors of the chats. High connectivity, the rapid creation of support networks, the fact that we are "protected" in our homes may have been some of the factors for the experience of coping with what was happening in real-time. We are experiencing a historic online Psychodrama Congress.

Through the virtual tele phenomenon, sociometry has developed as the electronic device screen has become a resource that has contributed to unveiling the contents of the dynamic socio-cultural matrix. The maintenance of the bond, the encounter and the sociometric confrontation was sustained based on the performance of the therapeutic agents in the virtual environment.

Let us give more examples of the hypersupplementary reality: in some sociodramas, we did group warming related to the feelings experienced during the pandemic. The ones that came up the most were anguish, fear, loneliness and discouragement. We left the moment of dramatization marked and asked the participants to represent these feelings as characters who received their scripts from the audience. The interaction between characters and between them and the audience made the drama dense. Spontaneously or at the director's request, new characters emerged from the audience, such as "strength" and "optimism". They interposed about the power of the characters' "fear" and "anguish". We asked to close the dramatization and, in sharing, the participants said: "I did not even realize that the screen was between us, I lived the characters intensely"; "It felt like I was in another dimension, in front of my computer"; "At first, I found so much dialogue strange, but suddenly I found myself entering like a character on the screen"; "It felt like a dream and the computer as an input channel...". 
We observed that the warming-up in the virtual environment could boost and maximize the imaginary in the experience of online dramatization.

Other examples occurred during the initial months of the pandemic when we conducted sociodramas about the digital inclusion of psychodramatists. We observed many excited colleagues who were taking action online; however, most were suffering: they wanted to give up their profession; they were anxious about the need to retrain the professional role; there was a prevalence of feelings of insecurity, fear, loneliness, helplessness and anguish; various types of resistance and stoppages. After exposing these feelings and some scenes, we demarcated the online dramatization of a chosen scene. At that time, the participants warmed up to the characters and played them intensely, and occasionally we used the action techniques. In sharing, some colleagues said: "I never thought that even though virtual means, I could live this scene so intensely"; "I am more relaxed because I saw it possible to dramatize, and it seemed like a giant wave of creativity".

In their dramatic context, online action methods maximize the supplementary reality, making it a hypersupplementary reality. It results from the experience of the imaginary in the virtual environment, from the virtuality that concretizes the "as if" of psychodrama.

During the sociatric session, scenes also intersect: the interchange of cultures, beliefs, emotions, scenes, and characters. The group (or the psychotherapist and the patient) exposes content with which the members identify or conflict. The intersection of scenes is the unveiled content of the co-unconscious, shared in the confrontation and encounter of the therapeutic act.

We constantly ask to what extent our intersecting scenes, with ideological and historical positions, interfere in our practices (Merengué, 2020). Co-conscious and co-unconscious content can direct us towards spontaneity-creativity or the maintenance of oppressive systems. Vieira (2020) points out the risks of reproducing, in therapeutic practice, the fascist, slavery, neoliberal, sexist, homophobic, socio-cultural matrix, which sickens and cancels subjects and groups in society. This attention is essential in all of our practices, online or in person.

\section{CONDENSED CORPORALITY AND SPEECH-ACTION}

The virtual therapeutic bond creates new forms of warm-up on us since the virtual environment brings restrictions about corporeality and contact. In a public psychodrama, held in July 2020, the director tells us: "Imagine that we are in our building looking at people from their windows. We entered their homes. We know other realities from our screens. We are together for a date". The participants, from that slogan, looked at each other and smiled at each other. Facial expressions were intense. They started to say how they felt in that building, and when they saw people, they said that they felt "at home" with each one. And the scenes emerged from the emotions of that experience.

In warm-ups and dramatizations, facial and gestural expressions predominate, and we can stand up and act in front of the cameras. These and other possibilities of body expression and action point to condensed corporeality in the scenes. Condensed corporeality is the body of the psychotherapist or the patient, or the members of the group, mediated by the screen, which presents itself intensely and in its entirety, but in the restriction of the image. There is the presence of the physical bodies of the participants, however, through the screen. In the virtual environment, the expression of minimal facial movements, of the hands, of a tic, of the arms, of a way of looking, starts to take the place of the whole body in the scene. How the person speaks, how they behave in their space in front of the screen, their way of dressing, the place where they are, all this tells us and wants to tell us.

Corporality condensed with speech-action will bring important content to the virtual session. Speech-action is the speech that contains the scene with its characters, the speech that brings culture and composes conserved behaviors. Each person has an expressive verbal modality of their subjectivity (Nery, 2018). In speech-action, we observe who speaks, in the here-now, through the subject, which ideologies, beliefs and institutions speak and for what.

A patient told me that she is distressed because her desire to be a "super mom" is increasingly frustrated, as she has a job and a personal life to live. I asked, “Where does this supermom' character come from?”. And she quickly replies: "Ab! Everyone says that we have to be superwomen, super mothers... I rarely hear a complaint from the mothers I know. However, today I am taking on my complaints! I have already left many things in my life because I am only a mother?". 
In this speech-action, we observe the "other" of society with its cultural conserves building our characters and attempting to de-potentialize them.

And I ask, "What did you want to be that super mom for?" She replies: "So that my son doesn't complain about me".

At that moment, we found the affective logic of conduct: not to frustrate the child, to be loved by him. For Nery (2018), the affective logic of conduct guides our roles by building characteristics in the search for acceptance, group belonging, or attempting to demonstrate suffering with the non-acceptance of the other (s).

We continue the question: "Whom would you like to be a 'super mom' in your life?" She replies: "My mother". I asked, "What mother was your mother?" She replies in a choked voice: "I did not feel cared for, supported, respected. I did not feel her presence, she always prioritized other activities".

We observe the conserved character "mother", who blocks her spontaneity-creativity.

The patient says: "And I suffered from this absence, I was always angry with my mother".

In this speech action, we observe the "inner child" who builds the desire to have and be a super mom.

I asked the patient to move away from the camera and image the role of the mother. She stood up, made a position to carry the child on her lap, looked at her and smiled.

In this image, the patient appeared only partially, her face and arms. The condensed corporeality present in the virtual environment produced effects similar to that of a face-to-face job, with many emotions and dialogues between mother and child. Condensed corporality focuses on body expressions that speak of the entire physical body present in the session and present in the image on the screen.

The patient, seeing herself in a mirror of her image, made by me, said: "Today, I can see other angles of my history, while I am a mother. I can be a mother in my way, with less guilt".

We observed a crossing of scenes, emotions and beliefs in the bonds. Psychotherapy expands the co-unconscious of the mother-daughter relationship, the daughter-mother-son, therapist-patient, and everyone related to the cultural guidelines for conduct.

Psychotherapy or online sociatry works with condensed and imaginary corporeality, which is exposed in minimal physical expressions, speech-action, and the resources of the virtual platform. Condensed corporeality is the body that presents itself as physical for itself and the other but mediated by the screen. We capture parts of body expressions in the online instant that speak of the physical bodies of those present and jointly create the scenes.

\section{IMPORTANCE OF AUXILIARY EGO IN ONLINE ACTION METHODS}

In the field of virtuality, there are, among other phenomena, fugacity, rapid changes, high connectivity and liquidity in relationships (Bauman, 2001). To be distracted in a moment of the virtual meeting, for example, someone from the social context approaches, a noise beside, or we can turn off the electronic device when we do not want to be upset when we have resistance to tensions or fear something.

According to Vidal and Castro (2020), these specificities of the virtual world demand the spontaneous action of the psychodramatist towards the client(s). In online action methods, we observe, for example, that the director and the auxiliary ego, in order to maintain the warm-up, have a greater need for concentration, approximation of the patient (or group's) experiences, of making doubles and readiness to play the protagonist's characters.

It is also important the participation of auxiliary egos in works in which the participants have no practice with psychodrama. In a work in an alternative energy company about online leadership, the team worked on several scenes to train the role of leader or to mediate conflicts as an audience. In one of the meetings, the protagonist scene of the participants was the difficulty of communicating with the superiors. There was a fear of not transmitting activity reports to them or making proposals about its problems. I asked if we could work on this scene, like role training. They looked at each other and were silent with a smile. This condensed corporeality showed me that they had limitations in their performance. I asked if they feared exposing themselves there in the dramatization; they said yes. I realized, then, that the warm-up could occur through the trained auxiliary ego present at the event. I asked him to imagine himself as a member of the team, with the scripts 
already given. The ego made the character, also increasing it with doubles and soliloquies. I played the character of fear, and there was a dialogue. I asked if anyone could play this character. One person applied. The dialogue was intense, and others participated in helping the colleague. At one point, another colleague spontaneously said that he was the most authoritative superior. Moreover, the action was intense, with the help of everyone, in the collective creation.

The auxiliary ego function and the role of the auxiliary ego are fundamental for maintaining warmth in the virtual environment, promoting the hypersupplementary reality, and bringing the patient's (and group's members) speech-action to life and to work on corporeality condensed explored as the whole body.

\section{FINAL CONSIDERATIONS}

We try to understand, with this study, some specificities of online sociatrics. The meaning zones brought indicators that shed light on the phenomena and helped us verify the hypothesis that psychodrama and other methods of online action maximize the supplementary reality in the dramatic context, that is, that in the dramatic context, we live the reality hypersupplementary. There is an experience of a "dream", an "as if" in action through the computer screen. In the digital environment, we give wings to fantasy by experiencing dramatization, and we live a reality multiplied by the virtual and the imaginary.

On the hypothesis that the minimal body expressions and the resources of the virtual platform contribute to the development of the session, on the screen of the electronic device, the condensed and imaginary corporality gives life to the speech-action, which brings the contents of the dynamic socio-cultural matrix. We suggest that the specificities of the presence of the body in the online session be increasingly researched.

We observed the need for comparative studies of virtual and face-to-face care to verify the hypothesis that the therapeutic bond in the virtual environment demands greater availability of the auxiliary ego or the auxiliary ego function of the director for the maintenance of the warm-up, the differentiation and sharing of the scenes that intersect.

At the moment, we observed that the functional unit, the auxiliary ego and leadership functions of the director expand, in the digital environment, the therapeutic sharing that occurs through the intersection of scenes, characters and feelings. And so we live, through technology, the virtual tele that develops the sociometry of relationships and groups. We still observe that the therapeutic act, in the virtual platforms, also constitutes a political act when working our cultural conserves that produce suffering.

Online sociatry needs many studies to make the virtual environment more humane. In this sense, it is important to go deeper into virtuality and virtual reality (VR), which is not limited to virtual environments and platforms on the internet but several advanced technological devices for the virtual experience.

After a comprehensive review of online psychotherapy, Riva (2005) states that VR will increasingly be part of psychology, and it needs to be defined broadly. Moreover, for Gualeni et al. (2017), techniques that use characters and scenes for psychotherapy are likely to become more relevant with the increasing diffusion of virtual technologies in social practices.

We seek to contribute to the collective creation of knowledge about online sociatrics. We hope that the reflections made can help in new studies.

\section{DATA STATEMENT AVAILABILITY}

All the data was generated in the current study.

\section{FUNDING}

Not applicable. 


\section{ACKNOWLEDGMENTS}

Not applicable.

\section{REFERENCES}

American Psychological Association (2013). Guidelines for the Practice of Telepsychology. American Psychologist, 68(9), 791-800. https://doi.org/10.1037/a0035001

Bachelard, G. (1994). O direito de sonhar (J. A. M. Pessanha, Trad.). Bertrand Brasil.

Bauman, Z. (2001). Modernidade líquida. Zahar.

Brito, V. (2006). Um convite à pesquisa: Epistemologia qualitativa e psicodrama. In A. M. Monteiro, A. M., D. Merengué, \& V. Brito (Orgs.), Pesquisa qualitativa e psicodrama (pp. 15-56). Ágora.

Echenique, M. (Org.). (2021). Psicodrama Virtual: Explorando a toca do coelho. Araucária.

Fleury, H. J. (2020). Psicodrama e as especificidades da psicoterapia on-line. Revista Brasileira de Psicodrama, 28(1), 1-4. https://doi.org/10.15329/2318-0498.20203

González-Rey, F. (2002). Pesquisa qualitativa em psicologia: Caminhos e desafios (M. A. F. Silva, Trad.). Pioneira Thomson Learning. (Obra original publicada em 1999).

Gualeni, S., Vella, D., \& Harrington, J. (2017). De-Roling from Experiences and Identities in Virtual World. Journal of Virtual Worlds Research, 10(2), 1-18. https://doi.org/10.4101/jvwr.v10i2.7268

Imholz, S. (2008). The therapeutic stage encounters the virtual world. Thinking Skills and Creativity, 3(1), 47-52. https:// doi.org/10.1016/j.tsc.2008.02.001

Merengué, D. (2020). Descolonizando o psicodrama: Clínica e política. In A. Dedomênico, \& D. Merengué (Orgs.), Por uma vida espontânea e criadora: Psicodrama e Politica (pp. 37-59). Ágora.

Moreno, J. L. (1984). Psicodrama (3a ed., A. Cabral, Trad.). Cultrix. (Obra original publicada em 1946).

Moreno J. L. (1993). Psicoterapia de Grupo e Psicodrama (2a ed.). Editorial Psy.

Naffah, A., Neto (1997). Psicodrama: Descolonizando o imaginário. Plexus.

Nery, M. P. (2012). Grupos e Intervenção em Conflitos. Ágora.

Nery, M. P. (2018). Vinculo e Afetividade. Ágora.

Nery, M. P., Costa, L. F., \& Conceição, M. I. G. (2006). O Sociodrama como método de pesquisa qualitativa. Paidéia (Ribeirão Preto), 16(35), 305-313. https://doi.org/10.1590/S0103-863X2006000300002

Novotney, A. (2017). A growing wave of online therapy. American Psychological Association, 48(2), 48. https://www.apa.org/ monitor/2017/02/online-therapy

Pieta,M. A. M., \& Gomes, W. B. (2014). Psicoterapia pela Internet: Viável ou inviável? Psicologia: Ciência e Profissão, 34(1), 18-31. https://doi.org/10.1590/S1414-98932014000100003

Resolução CFP n. 11 (2018). Regulamenta a prestação de serviços psicológicos realizados por meios de tecnologias da informação e da comunicação e revoga a Resolução CFP n. 11/2012. Conselho Federal de Psicologia. https://atosoficiais. com.br/lei/orientacao-psicologica-pela-internet-cfp?origin=instituicao

Riva, G. (2005). Virtual Reality in Psychotherapy: Review. Cyberpsychology and Behavior, 8(2), 220-230. https://doi. org/10.1089/cpb.2005.8.220 
Thompson, R. B. (2016). Psychology at a Distance: Examining the Efficacy of Online Therapy. University Honors Theses. Paper 285. https://doi.org/10.15760/honors.292

Ulkovski, E. P., Silva, L. P. D., \& Ribeiro, A. B. (2017). Atendimento Psicológico online: Perspectivas e desafios atuais da psicoterapia. Revista de Iniciação Científica da Universidade Vale do Rio Verde, 7(1), 59-68. http://periodicos.unincor.br/ index.php/iniciacaocientifica/article/view/4029/3229

Vidal,G.P.,\&Castro,A.(2020).O Psicodrama clínico on-line:Uma conexão possível. Revista Brasileira de Psicodrama,28(1), 54-64. https://doi.org/10.15329/2318-0498.20196

Vieira, É. D. (2020). Possibilidades psicodramáticas de resistência ao fascismo contemporâneo. In A. Dedomênico, \& D. Merengué (Orgs.), Por uma vida espontânea e criadora: Psicodrama e Politica. (pp. 19-35). Ágora. 